\title{
THE INFLUENCE OF ELECTRONIC WORD OF MOUTH (E-WOM) PROMOTION OF STUDENT INTEREST IN BUYING SHARES: STUDY ON PNJ INVESMENT GALLERIES
}

\author{
Tetty Rimenda \\ rimenta@yahoo.com \\ Sabar Warsini \\ sabar.warsini@akuntansi.pnj.ac.id \\ R. Elly Mirati \\ Elly Mirati@gmail.com
}

\section{Accounting Department, Politeknik Negeri Jakarta \\ Politeknik Negeri Jakarta}

\begin{abstract}
The background of this research is lack students interest on buying shares. It arise the idea to do this study. Research begins with exploratory research to find out what promotion methods are most preferred to arouse their interest among viral marketing, referral marketing, and community marketing or buzz marketing. The unit analysis is 200 students who have a stock account at PNJ investment gallery. Statistic tool used in the study was multiple linear regression. The result shows that referral marketing, community marketing and buzz marketing influential promotion tools in arise student interest to buy shares. Furthermore, positive students' mindset is also an important factor to accept the promotion message easily.
\end{abstract}

Keywords: electronic word of mouth (EWOM), promotion, buying stock interest

\section{INTRODUCTION}

In recent years, the capital market in Indonesia has grown rapidly. The Government issued policies to stimulate national economic development by adjusting banking, capital market and non-bank financial industry regulations (Swa; July: 2015). One of the policies adjusted by the government is the Securities Brokerage Licensing Regulation (WPPE). With the issuance of this regulation, stock trading is facilitated and indirectly provides employment opportunities in the capital market. The implication of this regulation is the increasing stock trading. The Indonesia Stock Exchange (IDX) and securities companies are competing to market their shares to the public. The results of OJK's research concluded that segmentation of stock investors had shifted towards young consumers, therefore many securities companies targeted the target market to students.

Buying stocks requires a high level of trust, because stocks are products with a very high level of uncertainty. A person can get a return or loss. Before buying shares, investors usually look for information about the right stock to buy. Previous research concludes that the most easily obtained information about stocks is from Word of Mouth (WOM) [1]- [6]. Furthermore recommendations from capital market observers or recommendations from consumers who have already bought the share is fruitful [2]

E-WOM (Word of Mouth) is a new concept in the field of marketing [1]. e-WOM is a way to convey interpersonal messages from someone to others. So e-WOM is also known as personal recommendations, informal communication and informal advertising[9]. Furthermore, e-WOM influences consumer decision making in making purchases. Usually before making a purchase, consumers need input from other parties. Consumers are more convinced of the recommendations given by close friends or their families. So that trust is the key to success of e-WOM. In addition to being effective, e-WOM can also overcome consumer objections to products with relatively low costs. So that the media promotion using e-WOM is quite popular.

There are various types of e-WOM : (1) Viral Marketing: is a part of e-WOM that is designed to provide entertaining or informative messages (2) Referral Marketing: is part of eWOM that is designed so that consumers who 
are satisfied with the product can reference it by actively giving comments and reviews. (3) Community Marketing is part of e-WOM which consists of a small community (niche) that allows consumers to share information in the group (4) Buzz Marketing is part of e-WOM that doesn't have to be in touch with the internet.

Research on WOM that has been done by $\mathrm{Zu} \&$ Zhang [3], conclude that the development of information technology, makes consumers tend to seek information online Thus the role of e-WOM in promoting stocks is very important. Furthermore, before buying shares, consumers read the review then compare with other reviews . According to [1] the success of WOM is measured by the intensity of the WOM. WOM can praise or drop shares. Other studies conclude that women are more willing to take risks in online purchases, while men need _recommendations from friends or other parties before making an online purchase [4]-[5]- [7]. The literature review has found no research that examines WOM, but no one has specifically discussed the influence of wom on students who are just learning to buy shares. Through this research can provide input for designing the best promotion for introducing shares to students.

\section{Problem Statement}

The problem in this study is that PNJ GI's had not yet succeeded in increasing the number of investors and the number of transactions. It is assumed that the promotion carried out by PNJ GIs is not appropriate, so that an evaluation of the promotion methods that have been carried out is needed.

\section{Objectives}

The purpose of this study was to evaluate the promotional methods used in the PNJ GI. Furthermore, the effect of e-WOM (Viral Marketing, Referral Marketing, Community Marketing and Buzz Marketing) will be tested on the interest in buying shares

\section{LITERATURE REVIEW}

\section{Word of Mouth}

Previous research on WOM has proven that WOM influences consumer behavior. WOM is proven to influence awareness, consumer expectations, consumer perceptions, buying behavior and purchasing decisions. Initially WOM was only directed to one consumer, when marketer realized the power of consumers, WOM is directed to more than one consumers who will deliver messages to other consumers through social media networks. The role of marketing is in the process of delivering messages, so that messages can be received by more people.

\section{Electronic Word of Mouth (e-WOM)}

e-WOM (Word of Mouth) is not much different from WOM. (Goyette et al. 2010), eWOM is the delivery of messages from someone to other people by using interpersonal electronic media. So that e-WOM is also known as a personal recommendation, informal and informal advertising communication

There are various types of e-WOM that are known among marketing, namely:

a. Viral Marketing: is known as a strategy that can encourage people to deliver marketing messages to other parties among their friends and social networks. (Wilson, 2000). The specialty of viral marketing is its ability to duplicate marketing communication activities throughout the internet, so that the news quickly spreads. Like a virus that can quickly infect thousands of people, the influence of viral marketing is also very extraordinary. The key to viral marketing is communication from people per person in delivering messages, this is different from advertisements that messages are conveyed by companies to consumers. The spread of messages can be done intentionally or unintentionally. The concept of viral marketing suggests that marketers can increase the strength of interpersonal networks to promote something (Bryun \& Lilien 2008). Furthermore, Social Informationprocessing Theory emphasizes that delivering messages interpersonally is the main characteristic of viral marketing, where the message delivered is a reference for decision making.

b. Referral Marketing: Is a reference from someone who is satisfied when buying a product or services. From a marketing perspective, referral marketing is a positive or negative testimonial about the product or service being promoted. Positive impressions arise when the buyer is satisfied with the product or service he bought, otherwise negative testimonials arise because they disappointed with the 
product. ."Browsing and searching", on the internet takes a long time, sometimes causing frustration. So recommendations from those we trust like friends, family make search easier. ,Lun-Hsiao's (2010) Very often people decide to buy something because of the influence of a friend or family has bought it. Referrals can be done before or after a purchase. it can increase sales. In the stock market sector referrals are stock recommendations given by the media. According to Goyette et al 2010. Refrerral can be positive info and can also be negative info. In this study positive and negative info came from positive and negative observer recommendations

c. Community Marketing : People have different views about virtual communities, depending on the community they have. Virtual Community is a new social phenomenon in society that changes the way people communicate. To explain about virtual communities, people will usually refer to real communities. Virtual communities are defined as a group of people who share the same interests, the same goals that communicate online. (Kim, Yang, Kim: 2009) They discuss their interests and goals actively in groups that are done virtually. Group members vary, can be a lot also can be a little. (Wang, Yu, Fesenmaier; 2001) (Mc Kenzie- Moor, 2000). Groups that gather people who have the same hobbies, interests and preferences to be able to discuss their interests more freely. They do not need to know each other in real terms, but can be friendly in cyberspace, discuss various topics in their own ways. The influence of virtual communityFor is the same as the influence of WOM in the real world. Balasubramanian and Mahajan (2001).

d. Buzz Marketing:Buzz Marketing can be analogous to the spread of a gossip. Buzz is information by word of mouth, through endorser, which is important or popular people. Buzz marketing is a catalyst that can speed up or slow down the information provided (Goyette et al. 2010)Buzz marketing might be done through social media because the ownership of accounts in social media is free. Social media users come from various backgrounds. This is the reason social media has very powerful networking power. In other words, buzz marketing is a very effective promotional alternative for Netpreneur. When compared to viral marketing, the definition of buzz marketing is less clear, because it overlaps with other programs. The fact is that buzz marketing does not always use the internet and other electronic communication media. The purpose of buzz marketing is to create relationships (associations) between brands, products, or services with people chosen to be resource persons of marketing buzz.

\section{METHODOLOGY}

\section{Hypotheses Development}

Viral marketing is a part of e-WOM that makes entertaining or informative messages designed to be forwarded by each message recipient.[8]. The internet is the main component that makes messages viral. The message is like a virus that poisoned and affected everyone. In PNJ GI, information about stocks was made in slang language that could be understood by students, so that it was suspected that viral merketing influenced student interest in buying shares. So the first hypothesis developed in this research is:

\section{H1: Viral marketing affects students' interest in buying shares}

Referral Marketing: is part of e-WOM that makes programs where consumers who are satisfied with the product can refer it by actively giving comments, reviews [10]. Students are a group that relies heavily on their friends so that it is suspected that :

\section{H2: Referall marketing affects students' interest in buying shares}

Community Marketing is part of eWOM that forms a small community (niche) that allows consumers to share information about a product (eg fan clubs, and discussion forums).[11]. The small community in GI PNJ is groups that learn together about stock theory and discuss it in small groups. This group also often participates in capital market 
competitions. This group has strong and maintained communication. So that allegedly

\section{H3 : Community marketing influences the interest of students in buying shares}

Buzz Marketing is part of e-WOM but does not have to come into contact with the internet.[12] This is done by placing a credible person to explain the product. on GI PNJ, the task of explaining stock products is to lecturers, as well as assistance from securities companies, so that it is suspected that

\section{H4: Buzz marketing influences the interest of students in buying shares}

\section{Sample Selection}

Respondents were 200 people consisting of students who had accounts on GI PNJ. The age of the majority is 18 years, the sex of men and women is in a balanced amount. Data collection was carried out at the Jakarta State Polytechnic

\section{RESULT AND DISCUSSION}

Validity test is done by using a sample of 50 respondents. Validity test method uses Pearson Correlation test with a significance level of 0.01 ( 2 tails). While the reliability test uses the Cronbach's alpha method. The results of testing the validity and reliability show that viral marketing (cronbach's alpha $=0,907$ ), referral marketing (cronbach's alpha $=0,770$ ), community marketing (cronbach's alpha = 0,745 ), buzz marketing(cronbach's alpha = 0,845 ) and intention to buy shares (cronbach's alpha $=0,888)$, are valid and reliable. Next, processing data using regression analysis to measure the effect of each independent variable on the dependent variable indicated this study contributes to the understanding of factors influencing intention to buying share in GI PNJ. First, among the four factors of e-WOM affecting the intention to buying shares, Viral Marketing is the only one factor does not affect intention to buying share (reject H1). This result reflects that in buying shares, students need more detailed information. This is understandable, given the limited funds they have, so they are more careful in investing their funds So, decision maker should know that student who are bought shares did not influenced by viral marketing.

\section{Coefficients}

\begin{tabular}{|c|c|c|c|c|c|}
\hline \multirow{2}{*}{ Model } & \multicolumn{2}{|c|}{$\begin{array}{l}\text { Unstanda } \\
\text { rdized } \\
\text { Coefficie } \\
\text { nts } \\
\end{array}$} & \multirow{2}{*}{$\begin{array}{l}\text { Standardiz } \\
\text { ed } \\
\text { Coefficient } \\
\mathrm{s} \\
\text { Beta }\end{array}$} & \multirow{2}{*}{$t$} & \multirow{2}{*}{ Sig. } \\
\hline & B & $\begin{array}{l}\text { Std } \\
\text { Err } \\
\text { or }\end{array}$ & & & \\
\hline $\begin{array}{l}\text { (Con } \\
\text { stant } \\
\text { ) }\end{array}$ & $\begin{array}{l}- \\
.7 \\
14\end{array}$ & $\begin{array}{l}.43 \\
8\end{array}$ & & -1.630 & .105 \\
\hline VM & $\begin{array}{l}- \\
.0 \\
17\end{array}$ & $\begin{array}{l}.03 \\
5\end{array}$ & -.018 & -.494 & .622 \\
\hline $\mathrm{RM}$ & $\begin{array}{l}.1 \\
89\end{array}$ & $\begin{array}{l}.03 \\
9\end{array}$ & .224 & 4.865 & .000 \\
\hline $\mathrm{CM}$ & $\begin{array}{l}.1 \\
16\end{array}$ & $\begin{array}{l}.05 \\
5\end{array}$ & .131 & 2.109 & .037 \\
\hline BM & $\begin{array}{l}.5 \\
56\end{array}$ & $\begin{array}{l}.04 \\
3\end{array}$ & .657 & 12.806 & .000 \\
\hline
\end{tabular}

a. Dependent Variable: Minat

Second, our empirical results show that the impact of using referral marketing eWOM to intention to buy shares exists (H2). Compared with viral marketing, in referral marketing consist of trust, where student believe on other people experience, especially their friends. After they read reviews from friends become a kind of input to them to make decisions. Our research suggests that the referral marketing can use to raise the rate intention to buy shares in GI PNJ. Referral marketing influences students' interest in buying shares reflects that the role of references in buying shares is still very much needed by students.

Third, we also found that community marketing influences the intention to buy share (H3). Community marketing is groups formed by students to discuss opportunities to buy shares. What stocks should be purchased and what stocks do not need to be purchased. This means if students is include in a group of student who often discussed about share make them think they are on same boat with his friend so could increase their confidence, they will make some purchase decisions based on their community. Community marketing also dangerous if the community is misperception about share information. Therefore community marketing need some ways to avoid risks. The credible information is an important way for them. How to keep the credibility of the information source believable is a strategy needed to raise intention to buy share. 
Forth, the buzz marketing is an answer to keep the information source is important for student when they decided to buy share. (H4). Experience and credibility of information are significant. Because buying share always have of high risk, students always feel fear, uncertainty. It makes to make a decision is most complex and discussable. The opinion of experts in this matter is that lecturers or securities companies also greatly influence students' decision to buy shares. So that the discussion with experts can be further expanded These results indicate that the student group does have a positive influence, so that PNJ should facilitate in providing a good place for discussion for this student group

\section{REFERENCES}

Charness, Gary, Gneezy Uri (2012): Strong Evidence for Gender Differences in Risk Taking, Journal of Economic Behavior \& Organization 83, 50-58

Dwyer Peggy D., Gilkeson James H., List John A (2002) Gender differences in revealed risk taking: evidence from mutual fund investors, Economics Letters 76 (2002) 151-158

Erkan I \& Evans C (2016): Social media or shopping websites? The influence of eWOM on consumers' online purchase intentions, Journal of Marketing Communications

Garbarinoa Ellen \& Strahilevitzb Michal (2004): Gender differences in the perceived risk of buying online and the effects of receiving a site recommendation, Journal of Business Research 57, 768 - 775

Goyette I, Ricard L, Bergeron J, Marticotte F (2010): e-WOM Scale: Word-ofMouth Measurement Scale for eServices Context, Canadian Journal of Administrative Sciences Revue canadienne des sciences de l'administration 27: 5-23.

Hung, KH, Li SY (2007): The influence of e-WOM on Virtual ConsumerCommunities: Social Capital, Consumer Learning, and Behavioral Outcomes, Journal of Advertising Research 485 - 495
Kozinets RV, de Valck K. Wojnicki AC \& Wilner AJS (2010) Networked Narratives: UnderstandingWord-ofMouth Marketing in Online Communities, Journal of Marketing Vol. 74, 71-89

Park C, Wang Y, Yao Y \& Kang YR (2011): Factors Influencing eWOM Effects: Using Experience, Credibility, and Susceptibility, International Journal of Social Science and Humanity, Vol. 1, No. 1, $74-79$

Park C \& Lee TM (2009): Information direction, website reputation and eWOM effect: A moderating role of product type, Journal of Business Research 62 (2009) 61-6

Sun-Jae D, Jang-Sun H (2009): How Consumers Evaluate eWOM (Electronic Word-of-Mouth) Messages, Cyber Psychology \& Behavior Vol 12. No 2193 - 197

Temple LC, Mudambi, SM \& Temple DS (2011): Is it the Review or the Reviewer? A Multi-Method Approach to Determine the Antecedents of Online Review Helpfulness, Proceedings of the 44th Hawaii International Conference on System Sciences

[Zhu F, Zhang X (2010) : Impact of Online Consumer Reviews on Sales:The Moderating Role of Product and Consumer Characteristics, Journal of Marketing Vol. 74 (March 2010), 133-148 